\title{
KICS: A MODEL OF MOTIVATIONAL LEADERSHIP IN ORGANIZATIONS
}

\author{
John N. N. Ugoani \\ College of Management and Social Sciences, Nigeria \\ E-mail: drjohnugoani@yahoo.com
}

Submission: $18 / 02 / 2015$

Revision: 03/03/2015

Accept: 07/03/2015

\section{ABSTRACT}

This pure research produced a Model of Motivational Leadership KICS: which embraces knowledge, intelligence, collaboration and synergy. It is a synergistic proposition based on the theory of emotional intelligence as the index of competencies needed for effective leadership. It opened with a general discussion on traditional models of leadership, then the roles of knowledge, intelligence, collaboration and synergy as they relate to motivational leadership. Emotional intelligence clusters and synthesis of the model's elements were discussed, emphasizing how KICS-based motivational leadership can be developed and sustained. Motivational leadership entails exciting people's imaginations and inspiring them to move in a desired direction. It reflects the power to motivate and lead in organizations. Realizing that unity and cohesiveness are built from personal bonds, the best leaders seek to deepen their rapport with employees and colleagues to enhance organizational performance. The study argues that the synergy of related emotional intelligence competencies leads to motivational leadership behavior. Knowledge is critical to leadership because there are different types of leadership and different situations require different kinds of knowledge, and the person possessing the knowledge demanded by a certain situation in most cases, tends to become the best leader. A knowledgeable person is one who is trained to consider his actions to undertake them 
INDEPENDENT JOURNAL OF MANAGEMENT \& PRODUCTION (IJM\&P)

http://www.ijmp.jor.br

v. 6 , n. 3, July - September 2015

ISSN: 2236-269X

DOI: 10.14807/ijmp.v6i3.302

deliberately, in a disciplined manner. Added to this ability is the intelligence to endure in a chosen course in the face of distraction, confusion and difficulty, all combined in producing a motivational leader. Knowledge tends to be procedural in nature and to operate outside of focal awareness. It also reflects the structure of the situation more closely than it does in the structure of formal disciplinary knowledge. The survey research design was used for the study. Data generated were used to describe the KICS Model of Motivational Leadership.

Keywords: Transformational leadership, Transactional leadership, Charismatic leadership, Servant leadership, Visionary leadership, Inspired leadership, Disciplinary knowledge

\section{INTRODUCTION}

Traditional leadership scholars like Bass $(1985,1998,1990)$ tend to overemphasize the distinction between transformational and transactional leadership models in attempts to determine who is an effective leader in organizations. Joining the debate, Sternberg (2003) proposes WICS: Wisdom, Intelligence and Creativity Synthesized, as an important model of leadership in organizations.

While the debate rages on over what constitutes a fine model of leadership in organizations, the KICS: Knowledge, Intelligence, Collaboration and Synergy is a fresh impetus through the construct of Motivational Leadership Model towards who is an effective organizational leader. The model suggests that the four components of motivational leadership are Knowledge, Intelligence, Collaboration and Synergy (KICS).

The philosophy of the model is that an individual requires these important components interacting together in a synergistic manner so as to be a highly successful organizational leader. Despite the merits and demerits of transformational and transactional leadership models, motivational leadership model proposal aims at a leadership behavior that is highly relationship focused.

Leaders whether transformational or transactional are frequently rated by the level of admiration or none from their followers or subordinates, depending on the level of impact they have on them. Assuming that no individual is 'born' a leader it is then obvious that knowledge, intelligence, collaboration and synergy are to a certain 
DOI: 10.14807/ijmp.v6i3.302

degree ways of developing and sustaining motivational leadership because they interact in elimination of primitively which blocks interpersonal relationships.

The individual gains knowledge from the environment in ways that influence the level of intelligence, which enables him to collaborate with others as a team toward the achievement of organizational objectives. Knowledge of self, of others, and of groups, the intelligence to arrange and collaborate with others, lies at the heart of motivational leadership. Leadership is about warm relationships that influences and inspires others to do what the leader expects them to do without knowing it, or even feeling worried (GOLEMAN, 1998)

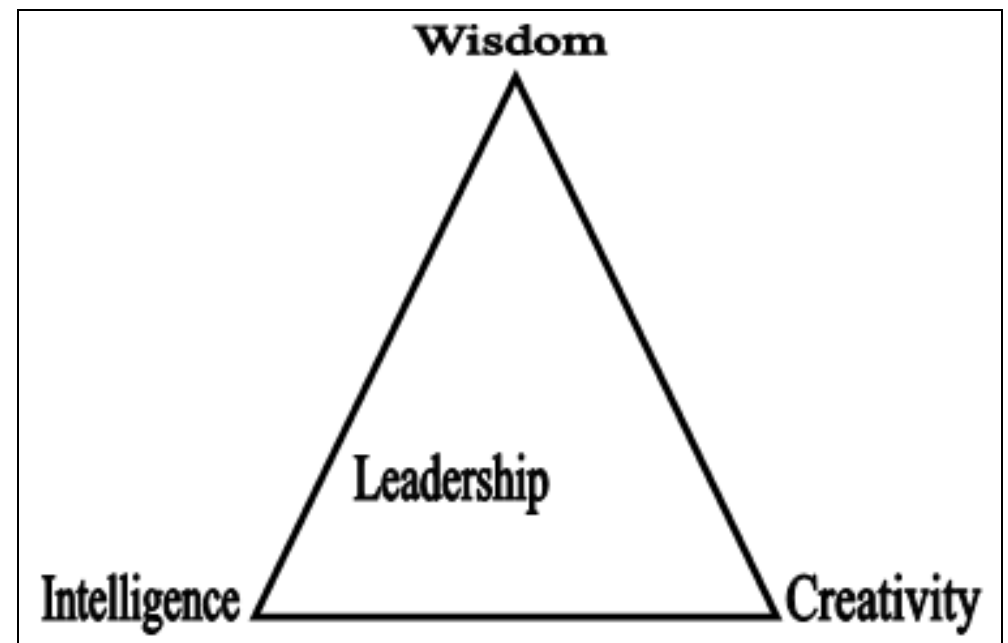

Figure 1: WICS: A Model of Leadership in Organizations Source: Sternberg (2003)

In his work Sternberg (2003) proposed The WICS Model of Leadership, and suggests that while management tends to be a formal, scientific, and presentoriented process, leadership tends to be an informal, flexible, inspirational, and future-oriented process. This perspective clearly suggests that leadership requires multiple intelligences embedded in the science of emotional intelligence.

Generally speaking, organizational leadership involves the process of guiding and directing the behavior of people in the work environment and a key to influencing organizational performance and effectiveness. The KICS model suggests that motivational leadership is the ingredient that drives organizational and human progress through knowledge, intelligence, empathize and synergy.

Motivational leaders inspire the people around them because they are able to develop good common identity, collaborate with others for common good, lead teams in the achievement of organizational objectives, avoid being autocratic, 
INDEPENDENT JOURNAL OF MANAGEMENT \& PRODUCTION (IJM\&P)

http://www.ijmp.jor.br

v. 6 , n. 3, July - September 2015

ISSN: 2236-269X

DOI: 10.14807/ijmp.v6i3.302

remain committed to a course and usually visionary. In contrast, lackluster leaders deplete the values of a people as they ruin organizations upon which society depends for sustenance. Their actions and inactions go on at huge costs against the organizations, employees, customers, and investors (RICHARDSON, 2010).

Motivation is intricately tied to leadership because it is directed towards changing the behavior of people. Motivation theories continue to show that it is a critical element of leadership that arouses enthusiasm, loyalty, passion and commitment to pursue a definite goal. Thus, motivational leadership involves the ability of the leader to change human behavior to move in the right direction. Since leadership requires a high dose of people skills, the imperative of KICS model of motivational leadership cannot be overemphasized.

The motivational leadership theory proposition is heavily in support of the transformational leadership concept. Transformational leadership inspires organizational success by dramatically affecting workers attitudes about what an organization should be as well as their basic values, such as trust, fairness, and reliability. Like transformational leadership, motivational leadership seeks to create in employees a sense of loyalty, ownership, commitment, encourages new ways of solving organizational problems and promotes lifelong learning through knowledge sharing (DAFT, 1999; GRAEF, 1993; YUKE, 1998).

\subsection{Four Components of KICS:}

\subsubsection{Knowledge}

Knowledge involves the leader ability for self-evaluation, the capacity or skill to identify, understand, examine, and manage the perspectives of others. According to Goleman (1998) the attainment of self-knowledge is humanity's greatest challenge, yet it is one of the greatest skills a person requires to be successful in leadership architecture. Knowledge of the self, the environment and the others is very critical for organizational leadership now that global organizations do more with knowledge employees.

Armstrong (2004) posits that knowledge is a necessary competitive tool for organizational success. Nonaka and Takeuchi (1995) state that knowledge is either explicit or tacit. Explicit knowledge refers to academic intelligence necessary for job performance while tacit knowledge has more to do with emotional intelligence which 
INDEPENDENT JOURNAL OF MANAGEMENT \& PRODUCTION (IJM\&P)

http://www.ijmp.jor.br

v. 6 , n. 3, July - September 2015

ISSN: 2236-269X

DOI: 10.14807/ijmp.v6i3.302

provides the skill for collaboration with others. Knowledge is important to organizational leadership success because management and leadership are qualitatively different concepts.

Ability to apply specialized procedures, techniques and knowledge required to get the job done, the ability to manage diversity and work well with others, and the ability to see the organization as a whole, to understand how the different parts of the organization affect each other, and recognize how the organization relates with the external environment are ingredients of knowledge that lead to motivational leadership in organizations. The latitude of human knowledge pushes back the frontiers of ignorance, opens the gate to human intelligence and widens the scope of interpersonal/human collaboration.

\subsubsection{Intelligence}

Intelligence provides the ability to take correct decisions. It is therefore an essential element of motivational leadership. A popular definition of intelligence is: "Intelligence is the aggregate or global capacity of the individual to think rationally and to deal effectively with his environment". Since intelligence is important to leadership, how important is it?

It is believed that if the conventional intelligence of a leader is too much higher than that of the group he or she leads, the leader may fail to connect with those people and becomes ineffective. Therefore, in addition to general intelligence, a leader requires intelligence in terms of emotional intelligence. Emotional intelligence may be defined as the capacity to reason about emotions, and of emotions to enhance thinking.

It includes the abilities to accurately perceive emotions, to access and generate emotions so as to assist thought, to understand emotions and emotional knowledge, and to reflectively regulate emotions so as to promote emotional and intellectual growth. Emotional intelligence complements academic intelligence, which has not provided the answer to successful leadership. The long-time primary emphasis on academic intelligence or intelligence quotient (IQ) in the literature relating intelligence to leadership perhaps has been unfortunate.

Presumably, some measure of academic intelligence is an ingredient of successful leadership, however, recent theorists emphasize other aspects of 
INDEPENDENT JOURNAL OF MANAGEMENT \& PRODUCTION (IJM\&P)

http://www.ijmp.jor.br

v. 6 , n. 3, July - September 2015

ISSN: 2236-269X

DOI: 10.14807/ijmp.v6i3.302

intelligence in their work, such as emotional intelligence. The leadership excellence at Johnson \& Johnson provides evidence of the romance of emotional intelligence and leadership in organizations. (STERNBERG, 2003; GOLEMAN, 1998 $; 1998^{\mathrm{b}}$; MCCLELLAND, 1973; SPENSER; SPENCER, 1993; MAINDL, et al. 1985)

\subsubsection{Collaboration}

Those excelling in leadership positions are those who are able to articulate and arouse enthusiasm for a shared vision and mission, step forward as needed and guide the performance of others, hold them accountable and lead by example. Collaboration is very important in the workplace of today. According to Goleman (1998) everything is done collaboratively.

There are no lone geniuses anywhere; ideas do not come from a lone head, but from collaboration. In a deep sense, collaboration matters immensely for leadership success in a world where work is done in teams. One of the most important skills in management or leadership is the ability to read the human perspective, to be aware of what is happening.

Power in leadership is the ability to make things happen, and to make things happen the leader must collaborate effectively, through understanding the human elements and move accordingly. Collaboration is the art of making an impact through people, the ability to pull people together, and to attract colleagues to work as a team for the achievement of organizational goals.

Gardner (1983) opines that the network of his associates is critical in work performance, suggesting that the group mind can be far more intelligent than the individual mind. The beauty of the art of collaboration cannot be overemphasized. For example, Goleman (1998) states that outstanding team performance raises the group intelligence quotient - the sum total of the best talents of each member on a team, contributes to their fullest.

When teams operate at their best, the results can be more than simply additive - they can be multiplicative, with the best talents of one person catalyzing the best of another to produce results far beyond what any one person might have done. The explanation lies in the members relationships. The motivation, interpersonal skills, and compatibility of the group members is the key to their performance. 
INDEPENDENT JOURNAL OF MANAGEMENT \& PRODUCTION (IJM\&P)

http://www.ijmp.jor.br

v. 6 , n. 3, July - September 2015

ISSN: 2236-269X

DOI: 10.14807/ijmp.v6i3.302

In contrast, according to Williams and Sternberg (1988) those who are socially inept, out of tune with others feelings are frequently a drag on success, especially if they lack the ability to resolve differences or communicate effectively and positively. Motivational leadership is strongly lied to collaboration because if group members receive proper recognition they become more committed to the goals and work harder.

\subsubsection{Synergy}

Many distinguished previous researchers have done a great deal of excellent work in the area of leadership. Models have also been created, but it would appear that there is no particular model of leadership theory that will completely embrace all its major components in an effort to determine who is a successful leader.

The KICS model is one of such models that may come nearer to some other models in capturing the components that are critical in producing quality leadership. The last component of the KICS model is synergy. The different elements of the model operates in cluster. The framework of the KICS model is emotional intelligence. Emotional intelligence is the index of knowledge, intelligence, collaboration among other competencies necessary for leadership success.

A leader requires knowledge to understand others and his or her environment, this knowledge provides the necessary level or type of intelligence to take appropriate decisions and actions. Intelligence as a basic leadership requirement gives rise to social skills - such as relationship management and collaboration. Emotional intelligence is a common phrase with which to focus attention on talent as it emphasizes links to all levels of the human psyche.

This dispositional variable is observed when a person demonstrates the competencies that constitute self - awareness, self-management social awareness and social skills at appropriate times and ways in sufficient frequency to be effective in the situation. Goleman (1998) posits that leadership is almost all about emotional intelligence. He explains that emotional intelligence invokes the capacity for recognizing our own feelings and those of others for motivating ourselves and others, and for managing emotions well in ourselves, and others and in our relationships. 
INDEPENDENT JOURNAL OF MANAGEMENT \& PRODUCTION (IJM\&P)

http://www.ijmp.jor.br

v. 6 , n. 3, July - September 2015

ISSN: 2236-269X

DOI: 10.14807/ijmp.v6i3.302

It describes abilities distinct from, but complementary to, academic intelligence, the purely cognitive capacities, measured by intelligence quotient. Emotional intelligence is the bedrock of emotional competencies that facilitate successful leadership. According to Goleman (1998) emotional competencies contribute about 80 percent in the success matrix of successful organizational leaders, and in contrast, lack of emotional attunement explains the failures of brilliant CEOS.

Emotional intelligence skills are synergistic with cognitive skills, top leaders have both - that is, knowledge, intelligence and social awareness. The more complex the task of leadership, the more emotional intelligence matters, because a deficiency in emotional intelligence can hinder the use of whatever technical expertise or intellect a leader may have. (SALOVEY; MAYER, 1990; BAR-ON, 1997)

\section{SYNERGISTIC PROPOSITION}

Cleary (1992) describes a model as a simplified representation of the world. He posits that the purpose of any model is to simplify and clarify thinking, to identify important aspects, to suggest explanations, and to predict consequences (DYE, 1992; FINEMAN, 1997).

Models have been widely employed in management theory to help clarify relationships and processes, including McGregor's (1960) theory ' $\mathrm{X}$ ' and theory ' $\mathrm{Y}$ ' model. Such significant studies confirm that models assist the researcher to understand the real world, and the reality of the researcher and make explicit the core competencies that would otherwise be hidden in an excess of words. Models suggest organization's core competencies that fit reality.

According to Drucker (1998), they must also fit one another, and be known, understood, and constantly tested throughout the organization. Drucker (1998) deems this essential and asserts that most organizations move to correct the culture of the organization before they accurately establish the assumption upon which the organization has been built.

The development of KICS Model of Motivational Leadership is a synergistic proposition and it is based on clusters of emotional intelligence competencies. Clusters within a competency model should be related in some way, like: knowledge, 
INDEPENDENT JOURNAL OF MANAGEMENT \& PRODUCTION (IJM\&P)

http://www.ijmp.jor.br

v. 6 , n. 3, July - September 2015

ISSN: 2236-269X

DOI: 10.14807/ijmp.v6i3.302

intelligence, collaboration and synergy - and not a list. They may be related as being parts of a whole.

In other words, the clusters might complement each other like in the KICS Model the competencies of knowledge, intelligence and collaboration are social skills. Demonstrating the competencies in one of these clusters does not preclude nor arouse the competencies in the other cluster but when demonstrated in conjunction with each other the individual is typically more effective in leadership and professional management positions.

The clusters within a model may have a developmental relationship. For example, the knowledge cluster of competencies is needed for sustainable intelligence, and the intelligence cluster required for superior collaboration. Also effective clusters may have compensatory relationships. For example, the collaboration cluster may occasionally compensate for the demonstration of the other clusters.

The clusters of a competency model is not by accident, rather they offer an appropriate focal point from which to identify, predict and establish the multiple levels of causal connections as suggested in the KICS Model. Rather than by accident, the clusters of a competency model make sense and come out of our mental and theoretical models (BALLON, et al. 1999; BOYATZIS, 1982; BOYETZIS, et al. 2000; CAVALLO; BRIENZA, 2002; BOYATZIS, 1999).

Goleman (1998) posits that for outstanding leaders, emotional competencies - as opposed to technical or cognitive cues - make up 80 to 90 percent of those listed as crucial for success. In model building, emotional intelligence competencies are put in synergistic clusters. Clusters are behavioral groups of the designed competencies.

They are often linked conceptually and defined by a theory as an operationalization framework to describe which competencies are associated with others. The competencies within such a cluster may be linked empirically to allow us discover how the human organism demonstrates these desired competencies in various situations.

In a classic work, McClelland (1973) posits that competence comes in multiples. Organizations and individuals interface in ways that require a multitude of 
INDEPENDENT JOURNAL OF MANAGEMENT \& PRODUCTION (IJM\&P)

http://www.ijmp.jor.br

v. 6 , n. 3, July - September 2015

ISSN: 2236-269X

DOI: 10.14807/ijmp.v6i3.302

emotional intelligence abilities, each most effective when used in conjunction with others in synergistic clusters. The KICS Model of Motivational Leadership though a fresh conception is not too different from other previous models of leadership as it incorporates wonderful ideas of such models in continuation of the search for the ever elusive best leader. (BASS, 1998; BASS; AVOLIO, 1994; BASS, et al. 1996; CONGER; KANUNGO, 1998; MODASSIR; SINGH, 2008; HARMS; CREDE, 2010; UGOANI, 2014; MCCLELLAND, 1993)

\subsection{Motivational Leadership Theory}

One of the most applied constructs which emotional intelligence has been associated with is that of leadership. The leadership literature has produced many theories suggesting which characteristics compose the most effective leader. In addition to the major focus on transformational leadership, transactional leadership, charismatic leadership, servant leadership, visionary leadership, WICS Model, the race continues on what comprises the most effective leader (STERNBERG, 2003).

The KICS model comes from the idea that a combination of motives, skills and values determines how people lead in a given situation. The model is relationship oriented within the context of leadership theory that leads to a construct which lies outside the taxonomy of previous models. This provides an important distinction in as much as it bears directly on the operationalization of the model and the theories and hypotheses that are formulated about it.

Armstrong (2004) argues that knowledge emerges from the collective experience of work and is shared between members of a particular group or community, and that knowledge whether explicit or tacit is a social skill needed in leadership positions. For example tacit knowledge is a part of practical intelligence. Emotional Intelligence is based within the context of intelligence theory which integrates key ideas from the fields of intelligence and emotion thereby forming the index of a set of skills hypothesized to contribute positively to accurate self and group appraisal that may guide human behavior in a more prosocial manner (STERNBERG, 1998).

Prosocial behavior entails open communication and nurturing instrumental relationships with others. Motivational leadership is about quality relationships between the leader and the group. The best way to build quality relationship is to 
INDEPENDENT JOURNAL OF MANAGEMENT \& PRODUCTION (IJM\&P)

http://www.ijmp.jor.br

v. 6 , n. 3, July - September 2015

ISSN: 2236-269X

DOI: 10.14807/ijmp.v6i3.302

stay in contact with the individuals and the group. Since the art of leadership involves influence, it is better to move along with people and not ahead of them (MAXWELL, 2005; MAYER; SALOVEY, 1997; ABRAHAM, 2004; ADAIR, 2003).

Building relationships make employees feel inspired about their jobs and pass that loyalty to customers. Personal relationship means treating employees, customers and significant others with the highest respect. These elements are critical because leadership in organizations is the process of guiding and directing people in the work environment.

Cherniss and Goleman (2001) state that emotional intelligence affects the quality of relationships. They posit that relationships can help people become more emotionally intelligent and therefore contribute more toward organizational success. Management development strategies emphasize a way of imparting the skills and knowledge needed by organizational leaders to meet the strategic objectives of their organizations through helping, advising subordinates, controlling when necessary and providing feedback.

There is no single competence that can lead to success, rather a combination and a configuration of multiple competencies synergized can lead to organizational success. Studies suggest that effective leaders possess emotional intelligence which is the ability to recognize and manage emotion in oneself and in others. Emotional intelligence is made up of several competencies like knowledge, intelligence, collaboration, and they work more effectively in synergy with each other.

Nelson and Quick (2003) The person who gets the best out of his team, and meets overall expectations, compassionate, calm, and a great motivator, exhibits emotional intelligence, and a motivational leader. (BRYANT, 2003; BRIEF; WEISS, 2002; DIONNE, et al. 2004; CHERNISS, 2000; GLYNN, 1996; NWUGBE, 2010; ADUKWU - BOLUJOKO, 2010; BENNIS, 1989; ANONYMOUS, 2004; ARMSTRONG, 2004; ANTONAKIS, et al. 2009; BARDZILL; SLASK, 2003; BOYATZIS, 1995; NONAKA, 1994; CLAYTON, 1982; GENTILE, 1998; STERNBERG; KAUFMAN, 1993; KOTTER, 1990; ANONYMOUS, 2004)

\section{MATERIALS AND METHOD}

\subsection{Research Design}


INDEPENDENT JOURNAL OF MANAGEMENT \& PRODUCTION (IJM\&P)

http://www.ijmp.jor.br

v. 6 , n. 3, July - September 2015

ISSN: 2236-269X

DOI: 10.14807/ijmp.v6i3.302

The survey research design was used for the study. Surveys refer to an investigation into certain things or events that exist or occur at the time of the research and connected with some problem situations that is felt over a wide area by a large population. Surveys could either be descriptive or analytical.

\subsection{Population and Sample}

The target population comprised bank managers in Aba and Umuahia, Abia State, Nigeria. The sample was selected by the simple random sampling method, while the size was determined through the Yamane's technique.

\subsection{Instrument}

Primary data were collected through the use of a questionnaire titled "Motivational Leadership Questionnaire (MLQ). The 20-item instrument designed along the Likert-type scale had structured questions on leadership and emotional intelligence.

\subsection{Procedure for Data Collection}

All the 133 questionnaire copies were personally administered by the researcher and two research assistants. All the items were returned and found useful for the study.

\subsection{Data Analysis}

Data generated were used for the description and conceptualization of the KICS: Model of Motivational Leadership.

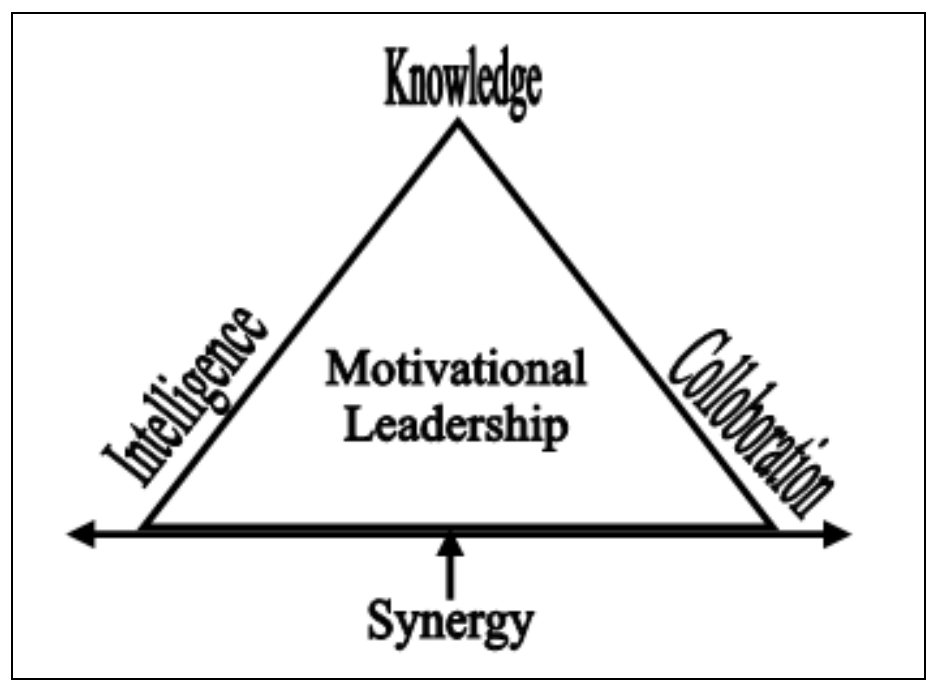

Figure 2: The KICS: Model of Motivational Leadership in Organizations Source: Ugoani, (2014) 
INDEPENDENT JOURNAL OF MANAGEMENT \& PRODUCTION (IJM\&P)

http://www.ijmp.jor.br

v. 6 , n. 3, July - September 2015

ISSN: 2236-269X

DOI: 10.14807/ijmp.v6i3.302

\section{DISCUSSION}

The KICS Model of Motivational Leadership is a synergetic proposition and asserts that the latitude of knowledge pushes back the frontiers of ignorance, opens up the gate to human intelligence and widens the window of interpersonal collaboration to produce prosocial human behaviors.

There is ample empirical evidence that this model is strongly theoretically, related to the concept of emotional intelligence which is the index of the competencies required for effective prosocial organizational behaviors. Leadership as an art of influence involves articulating and causing enthusiasm for a shared vision and mission, stepping forward to lead as the need arises, regardless of positions, guiding performance of others while yet holding them accountable and leading by example.

It is a social competence that is crucial for organizational success. In business organizations for example, good leaders are known for establishing rapport with their employees and using such emotional attunement to persuade and achieve excellent performance. Getting to know the employees by the Chief Executive Officer (CEO) provides a different type of motivation that arouses their enthusiasm for higher performance.

Goleman (1998) posits that the artful leader is attuned to the subtle undercurrents of emotion that pervades a group in an organization, and can read the impact of his or her own actions or inactions on those currents. One way leaders establish their credibility is by sensing these collective unspoken feelings and articulating them for the group, or acting in a way that tacitly shows they are understood.

In this sense the leader is a mirror reflecting back to the group its own experience. The leader is also a key source of the organization's emotional tone and image, because the excitement emanating from the leader can move an entire group in that direction, in this way, leadership gives energy to the people.

The matter of prosocial behavior is very important, because people not only pay close attention to leaders, they also tend to mimic them, either positively or negatively, and such actions and inactions have far-reaching effects on 
INDEPENDENT JOURNAL OF MANAGEMENT \& PRODUCTION (IJM\&P)

http://www.ijmp.jor.br

v. 6, n. 3, July - September 2015

ISSN: 2236-269X

DOI: 10.14807/ijmp.v6i3.302

organizational performance. Highly successful leaders exhibit high levels of positive behaviors that spread throughout the organization and the more positive the mood of a group leader, the more positive, helpful, co-operative are those in the group.

Leadership has emotional architecture because the ability to convey instructions convincingly, from the hearts, requires that a leader become sincere about the emotional message being delivered; truly believing that the message is what separates the motivational leader from the self-serving, manipulative leader. Motivational leadership entails exciting peoples' imaginations and inspiring them to move in a desired direction.

It takes more than simple power to motivate and lead in organizations. Realizing that unity and cohesiveness are built from personal bonds, the best leaders ensure to deepen their rapport with employees and colleagues which enhances organizational performance. This research argues that the synergy of related emotional intelligence competencies leads to motivational leadership behavior.

Knowledge is critical to leadership because there are different types of leadership and different situations require different kinds of knowledge, and the person possessing the knowledge demanded by a certain situation in most cases, tends to become the best leader. A knowledgeable person is one who is trained to consider his actions, to undertake them deliberately, in a disciplined manner.

Added to this ability is the intelligence to endure in a chosen course in the face of distraction, confusion and difficulty, all combined in producing a motivational leader. Knowledge tends to be procedural in nature and operates outside of focal awareness. It also reflects the structure of the situation more closely than it does in the structure of formal disciplinary knowledge.

\section{ACKNOWLEDGEMENTS}

The author is indebted to Professor R. J. Sternberg whose WICS Model of Leadership in Organizations provided the impetus for the conceptualization of the KICS Model of Motivational Leadership. Gratitude also goes to Bro. Emma Okorie, Chancellor, Rhema University, Professor, O. C. Onwudike, Vice Chancellor, Rhema University, and Professor, O. C. Nwaorgu, Dean, College of Management and Social 
INDEPENDENT JOURNAL OF MANAGEMENT \& PRODUCTION (IJM\&P)

http://www.ijmp.jor.br

v. 6, n. 3, July - September 2015

ISSN: 2236-269X

DOI: 10.14807/ijmp.v6i3.302

Sciences, Rhema University, for the provision of a conducive environment for academic work.

\section{REFERENCES}

ABRAHAM, R. (2004) Emotional Competence as antecedent to performance. A contingency framework. Genetic, Social and General Psychology Monographs, v. 130 , n. 2, p. 117-143.

ADAIR, J. (2003) How to grow leaders. The Seven principles of effective leadership development. Kogan Page London.

ADUKWU-BOLUJOKO, S. N. (2010) Inspired Leadership. Management in Nigeria, v. 46, n. 3 , p. $5-20$

ANONYMOUS, (2004) Leading by feel, Harvard Business Review, v. 82, n. 1, p. 27-28.

ANTONAKIS, J.; ASHKANASY, N.; DASHBOROUGH, M. (2009) Does leadership need emotional intelligence? The Leadership Quarterly, n. 20, p. 247-261.

ARMSTRONG, M. (2004) A handbook of Human Resource Management. $9^{\text {th }}$ edition, London Kogan Page.

AVOLIO, B. (1999) Full Leadership: Building the vital forces in organizations.

Thousand Oaks, C. A. Sage.

AVOLIO, B. J.; BASS, B. M.; JUNG, D. I. (1999) Reexaming the components of transformational and transactional leadership using the Multifactor Leadership Questionnaire. Journal of Occupational and Organizational Psychology. n. 72, p. 441-462.

BALLON, R.; BOWERS, D.; BOYATZIS, R. E.; KOLB, D. A. (1999) Fellowship in Lifelong Learning: An Executive Development Programme for advanced professionals. Journal of Management Education, v. 23, n. 4, p. 338-354.

BARDZILL, P.; SLASKI, M. (2003) Emotional intelligence: Fundamental Competencies for enhanced Service provision. Managing Service Quality, v. 13, n. 2, p. 97-104.

BAR-ON, R. (1997), The Emotional Quotient Inventory (EQ-i) A Test of Emotional Intelligence. Toronto: Multi-Health Systems.

BASS, B. M. (1985) Leadership and Performance beyond expectation. New York. Free Press.

BASS, B. M. (1990) Bass and Stogdills's Handbook of Leadership, Theory, Research and managerial applications. New York, The Free Press

BASS, B. M. (1998) Two decades of research and development in transformational leadership. European Journal of Work and Organizational Psychology, n. 8, p. 932.

BASS, B. M. (2002) Cognitive Social and Emotional Intelligence of

Transformational Leaders. Multiple Intelligences and Leadership p. 105-118

BASS B. M.; AVOLIO, B. (1994) Full Range Leadership Development. Manual for the Multifactor Leadership Questionnaires. Palo Alto, C. A: Mind Garden. 
BENNIS, W. (1989) Why Leaders Can't lead: The Unconscious Conspiracy Continues. San Francisco. Jossy - Bass Publishers.

BOYATZIS, R. E.; GOLEMAN, D.; RHEA, K. (2000) Clustering Competence in Emotional Intelligence: Insists from the Emotional Competence Inventory (ECI) Ohio, The Hay/McBer Group

BOYATZIS, R. E. (1982) The Competent Manager. A Model for effective Performance. New York, John Wiley \& Sons.

BOYATZIS, R. E. (1994) Stimulating Self-directed learning through the management assessment and development course. Journal of Management Education, v. 18, n. 3, p. 304-323

BOYATZIS, R. E, (1995) Innovations in prosocial Education: Steps on a journey from teaching to learning. San Francisco. Jossey-Bass

BRIEF, A.; WEISS, A. (2002) Organizational behaviour Affect in the Workplace. Annual Review Psychology, n. 53, p. 279-307.

BRYANT, S. E. (2003) The role of transformational and transactional leadership in creating, sharing and exploiting organizational knowledge. Journal of Leadership and Organizational Studies, v. 9 n. 4, p. 32-44.

CAVALLO, K.; BRIENZA, D. (2002) Emotional Competence and Leadership excellence at Johnson \& Johnson: The emotional intelligence and leadership study. Retrieved November 10, 2002, from http://www.eiconsortium.org

CLAYTON, V. (1982) Wisdom and Intelligence: The nature and function of knowledge in the later years. International Journal of Aging and Development, $n$. 15 , p. 315-321

CLEARY, R. (1992) Models as effective research tools. In: Cavanagh, D. M.; Rodewell, G. M. (Eds.) Dialogues in Educational Research. Darwin, N.T. William Michael Press.

CHERNISS, C. (2000) Emotional Intelligence: What it is and why it matters. Paper presented at the Annual Meeting of the Society for Industrial and Organizational Psychology, New Orleans, LA.

CHERNISS, C.; GOLEMAN, D. (2001) The Emotionally Intelligent Workplace, San Francisco, Jossy-Bass.

CONGER, J. A.; KANUNGO, R. (1988) Charismatic Leadership: The elusive factor in organizational effectiveness. San Franscisco: Jossy-Bass.

DAFT, R. L. (1999) Leadership: Theory and Practice. New York, Dryden Press.

DIONNE, S.; YAMMARINN, F.; ATWATER, L.; SPANGLER, W. (2004)

Transformational leadership and team performance. Journal of Organizational

Change Management, v. 17, n. 2, p. 177-193.

GARDNER, H. (1983) Frames of Mind: The theory of multiple intelligence. New York, Basic Books.

Gentile, M. C. (1998) Managerial Excellence Through Diversity. Text \& Cases, USA Waveland Press Inc.

GLYNN, M. A. (1996) A Framework for Relating Individual and Organizational Intelligence to Innovation. Academy of Management Review, n. 21. 
INDEPENDENT JOURNAL OF MANAGEMENT \& PRODUCTION (IJM\&P)

http://www.ijmp.jor.br

v. 6, n. 3, July - September 2015

ISSN: 2236-269X

DOI: 10.14807/ijmp.v6i3.302

GOLEMAN, D. (1995) Emotional Intelligence: Why it can matter more than IQ. New York, Bantam Books.

GOLEMAN, D. $\left(1998^{\mathrm{a}}\right)$ Working with Emotional Intelligence, New York, Bantam Books

GOLEMAN, D. $\left(1998^{\mathrm{b}}\right)$ What makes a good leader? Harvard Business Review, November/December, p. 93-102

GOLEMAN, D. (2001) An El-Based Theory of Performance. In CHERNISS, C.; GOLEMAN, D. (Eds). The Emotionally Intelligent Workplace: p 27-45. San Francisco Jossey-Bass

GOLEMAN, D.; BOYATZIS R. E.; MCKEE, A. (2002) Primal Leadership: Realizing the power of Emotional Intelligence Boston Harvard Business School Press p:39

GRAEF, C. L. (1993) The Situational Leadership Theory: A Critical Review.

Academy of Management Review, n. 8, p. 285-296.

DRUCKER, P.F. (1998) Reter Drucker on the Profession of Management.

Boston: A Harvard Business Review Book.

DYE, T.R. (1992) Understanding Public Policy. Englewood Cliff, N.J Prentice Hall.

FINEMAN, S. (1997) Emotion and Management Learning. Management Learning, v. 28 , n. 1 , p. $16-25$.

HARMS, P. D.; CREDE, M. (2010) Emotional Intelligence and Transformational and Transactional Leadership. A meta-analysis. Journal of Leadership \&

Organizational Studies, v. 17, n. 1, p: 5-17.

KOTTER, J. P. (1990) What Leaders Really Do. Harvard Business Review.

MANDELL, B.; PHERWANI, S. (2003) Relationship between Emotional intelligence and Transformational Leadership Style: A gender comparison. Journal of Business and Psychology, v. 17, n. 3, p. 387-404

MAXWELL, J. C. (2005) The $360^{\circ}$ Leader. Tennessee Thomas Nelson Inc.

MAYER, J. D.; SALOVEY, P. (1997) What is emotional Intelligence? Emotional development and emotional intelligence: Educational Implications. New York, Basic Books.

MCCLELLAND, D. C. (1973) Testing for Competence Rather than Intelligence.

American Psychologist, n. 46.

MCCLELLAND, D. C. (1985) How motives, skills, and values determine what people do. American psychologist, n. 40, p. 812-825.

MCCLELLAND, D. C. (1993) Intelligence is not the best predictor of job performance. Current Directions in Psychological Research, n. 2, p. 5-8.

MCGREGOR, D. (1960) The human side of Enterprise. New York, McGraw Hill.

MEIDL, J. R.; EHRLICH, S. B.; DUKERICH, J. M. (1985) The Romance of Leadership. Administrative Science Quarterly, n. 30, p. 78-102.

MODASSIR, A.; SINGH, T. (2008) Relationship of emotional intelligence with transformational leadership and organizational citizenship behavior. International Journal of Leadership Studies. v. 4, n. 1, p. 3-21 
INDEPENDENT JOURNAL OF MANAGEMENT \& PRODUCTION (IJM\&P)

http://www.ijmp.jor.br

v. 6 , n. 3, July - September 2015

ISSN: 2236-269X

DOI: 10.14807/ijmp.v6i3.302

NELSON, D. L.; QUICK, J. C. (2003) Organizational Behavior. Foundations, Realities and Challenges. $4^{\text {th }}$ edition, USA, South-Western Publishing Co.

NGWUBE, I. M. (2010) Leadership for change. Management in Nigeria, v. 46, n. 3 p. 7-14.

NONAKA, I, (1994) A dynamic theory of organizational knowledge creation. Organizational Science 5, p. 14-37

NONAKA, I.; TAKEUCHI, H. (1995) The knowledge creating company. Oxford University Press. New York.

RICHARDSON, P. (2010) The Impact of Education on Leadership Development. Management in Nigeria. v. 46, n. 3, p. 47-50

SALOVEY, P.; MAYER, J. D. (1990) Emotional Intelligence. Imaginations, cognitions, and personality, v. 9, n. 3, p. 185-211

SPENCER, L. M. JR.; SPENCER, S. M. (1993) Competence at work: models for superior performance. New York, John Wiley and Sons.

STERNBERG, R. J. (2003) WICS: A model of leadership in organization, Academy of Management Learning and Education. v. 2, n. 4, p. 386-401

STERNBERG, R. J. (1995) Theory and measurement of tacit knowledge as a part of practical intelligence. 203-319-334

STERNBERG, R. J. (1998) Successful intelligence. How practical and creative intelligence determine success in life. New York, Plume.

STERNBERG, R. J.; KAUFMAN, J. C. (1993) Human abilities. Annual Review of Psychology, n. 49, p. 479-502

UGOANI, J. N. N. (2014) Effect of tacit Knowledge on Business Success among Igbo Traders. Management and Administrative Sciences Review, v. 3, n. 1, p. 120-128.

WILLIAMS, W. M.; STERNBERG, R. J. (1988) Groups Intelligence: Why some groups are better than others. Intelligence, n. 12.

YUKE, G. (1998) Leadership in Organizations, $4^{\text {th }}$ edition, New York, Prentice Hall. 